FACTA UNIVERSITATIS

Series: Physical Education and Sport Vol. 15, N 3, 2017, pp. 493 - 499

https://doi.org/10.22190/FUPES1703493V

Original research article

\title{
THE EFFECTS OF PROGRAMMED TRAINING ON DEVELOPMENT OF EXPLOSIVE STRENGTH IN FEMALE VOLLEYBALL PLAYERS
}

\author{
UDC 796:012.1
}

\section{Marina Veličković, Ivana Bojić, Dragana Berić}

Faculty of Sport and Physical Education, University of Niš, Niš, Serbia

\begin{abstract}
This study was done with the aim of determining the effects a programmed training would have on the changes in the explosive strength of young female volleyball players. The sample consisted of 30 female volleyball players, aged 14 to 16, divided into two groups - the experimental one $(n=15)$ and the control group $(n=15)$. The experimental group was comprised of the players from the club OK 'Desetka', who, apart from the basic technical and tactical training process, underwent a specially designed programme for developing explosive strength two times a week (on Tuesdays and Thursdays). The experimental programme was applied during the period of preparations before the official beginning of the regional competitions for cadets. The control group was comprised of the players from the club OK 'Millennium', who, during the same period of time, underwent only those training sessions which had previously been planned within the annual plan and programme of the club. Explosive strength evaluation included four sets of tests: the squat jump (SJ), countermowement jump (CMJ), drop jump $(D J)$, one-legged CMJ (OLCMJ). The effects of the progremmed training on the development of the explosive strength of the young female volleyball players was determined by the Covariance Analysis, ANCOVA. The results obtained in such a way showed the statistically significant improvement in the parameters tested within the experimental group. The difference was insignificant in the OLCMJ test only. The results point to the conclusion that the experimental training programme had positive effects on the changes of explosive strength of young female volleyball players.
\end{abstract}

Key words: Volleyball, motor abilities, explosive strength, agility, effects

Received April 12, 2017/ Accepted January 15, 2018

Corresponding author: Marina Veličković

Faculty of Sport and Physical Education, University of Niš, St. Čarnojevića 18, 18000 Niš, Serbia

Phone: +381 $18510900 •$ E-mail: marina.velickovic@live.com 


\section{INTRODUCTION}

Volleyball is an acyclic sport with short and fast direction changes, a multitude of jumps and landings (falls) and ball hitting. It belongs to the group of anaerobic and aerobic sports. Depending on the number of sets, a volleyball match can last from 60 to 100 minutes. Each set lasts for approximately 20 minutes. There are more or less 50 actions per set. The break between the two actions lasts for about 15 seconds. During one match of 5 sets, a volleyball player performs between 250 and 300 actions, out of which 50-60\% jumps, $27-33 \%$ fast movements and direction changes within a limited space, 12 $17 \%$ landings and falls (Janković, Janković \& Đurković, 2003).

Muscle strength is most frequently defined as the ability to exert a maximal amount of force, which leads to the ambiguity between the notions of force and strength as man's basic abilities. Such definitions consequently result in incorrect identification of muscle strength with muscle force, since in mechanics strength is defined as the result of the force and speed applied, that is, the amount of work per time unit (Ignjatović \& Radovanović, 2013).

In volleyball, strength is characterized as the ability of a player to withstand and beat the external forces such as the inertia of the rotating ball, body weight, fractional force and gravitation, as well as the resistance to the elastic forces of the ball (Stojanović, Kostić, \& Nešić, 2005).

Vertical jump is one of the crucial factors which are directly linked to achieving maximal results in volleyball. $50 \%$ of the total of the training process should be devoted to practising and developing explosive features (Nejić, Herodek, Živković, \& Protić, 2010). The type of the load determines the speed and strength abilities performed within the anaerobic - non-lactate span of the energy source (Kovijanić, 2014).

The aim of this research was to determine the effects of a specially designed programme on the development of the explosive power while performing the vertical jump among female volleyball players aged 14 to 16 .

\section{METHODS}

\section{The sample of participants}

The sample was constituted of 30 female volleyball players, aged 14 to 16, from Nis, divided into two subgroups. The experimental group (E) was comprised of 15 players from the club OK 'Desetka', whereas the control group $(\mathrm{K})$ was comprised of 15 players from the club OK 'Millennium'.

\section{The sample of measuring instruments}

The sample of the measuring instruments for evaluating the explosive power included a set of four tests: the squat jump (SJ), squat jump with preparation (SMJ), depth jump (DJ), one leg squat jump with preparation (OLCMJ). All the measurements were take with the 'Optojump' device, and the parameter measured was the height of the jump in centimeters $(\mathrm{cm})$. 


\section{Experimental procedure}

The experimental programme lasted for 12 weeks (twice a week, in the introductory part of the training, lasting for 45 minutes). The whole experimental treatment was conducted during the period of preparations before the official beginning of the regional competitions for cadets. The players from the experimental group underwent, along with the experimental treatment, regular technical and tactical training sessions. The control group $(\mathrm{K})$ had only those training sessions which had previously been planned within the annual plan and programme of the club.

\section{Data analysis}

The data were analysed by the SPSS20 statistics programme. The effects of the complex training on the aforementioned abilities of the female volleyball players were determined by the covariance analysis ANCOVA. Before using this analysis, we had checked whether all the criteria required by it were met (normality of distribution, homogeneity of variance, the mesaurement of covariance, covariance reliability, homogeneity of the regression slopes). The normality of distribution was measured by the Kolmogorov-Smirnov test.

\section{RESULTS}

Table1 The normality of distribution of the results obtained in the initial measuring of the players of the experimental and control groups (Kolmogorov-Smirnov test).

\begin{tabular}{lccclccc}
\hline & E group & \multicolumn{5}{c}{ K group } \\
\hline Variables & Statistic & df & P & Variables & Statistic & df & P \\
\hline SJ & .076 & 15 & .200 & SJ & .128 & 15 & .200 \\
CMJ & .151 & 15 & .200 & CMJ & .157 & 15 & .200 \\
DJ & .086 & 15 & .200 & DJ & .169 & 15 & .200 \\
OLCMJ & .144 & 15 & .200 & OLCMJ & .140 & 15 & .200 \\
\hline
\end{tabular}

Table 1 presents the results of the Kolmogorov-Smirnov test, which show that the experimental and control group variables obtained in the initial measuring do not violate the assumption of the normality of distribution.

Table 2 The normality of distribution of the results obtained in the final measuring of the experimental and control groups (Kolmogorov-Smirnov test)

\begin{tabular}{|c|c|c|c|c|c|c|c|}
\hline \multicolumn{4}{|c|}{$\mathbf{E}$ group } & \multicolumn{4}{|c|}{$\mathbf{K}$ group } \\
\hline Variables & Statistic & $\mathrm{df}$ & $\mathrm{P}$ & Variables & Statistic & $\mathrm{df}$ & $\mathrm{p}$ \\
\hline SJ & .104 & 15 & .200 & SJ & .189 & 15 & .157 \\
\hline CMJ & .126 & 15 & 200 & CMJ & .117 & 15 & .200 \\
\hline DJ & . 169 & 15 & 200 & DJ & 191 & 15 & .148 \\
\hline OLCMJ & .173 & 15 & .200 & OLCMJ & .162 & 15 & .200 \\
\hline
\end{tabular}

The results obtained by the Kolmogorov-Smirnov test presented in table 2 show that there is normality of distribution $(\mathrm{p}<0.05)$ in almost all varibales in both experimental and control groups in the final measuring. 
Table 3 The homogeneity of variance (Levene's Test of Equality of Error Variances)

\begin{tabular}{lrrl}
\hline Variables & Statistic & df & $\mathrm{p}$ \\
\hline SJ & 1.916 & 15 & .177 \\
CMJ & 9.008 & 15 & $\mathbf{. 0 0 6}$ \\
DJ & .652 & 15 & .426 \\
OLMCJ & 1.034 & 15 & .318 \\
\hline
\end{tabular}

Based on the results presented in table 3, a slight deviation from the equality of variance in the CMJ variable $(\mathrm{p}<0.05)$ might be noticed. However, since the deviation is not significant, and as such allowed for by the variance analysis (Pallant, 2007), it will not pose a problem in further research.

Table 4 The homogeneity of regression slopes

\begin{tabular}{lrc}
\hline Variables & \multicolumn{1}{c}{$\mathrm{F}$} & $\mathrm{P}$ \\
\hline SJ &, 776 &, 386 \\
CMJ & .006 & .940 \\
DJ & 1.720 & .201 \\
OLMCJ & .284 & .599 \\
\hline
\end{tabular}

The results presented in table 4 show that there no deviations from the assumption of the homogeneity of the regression slopes in any of the variables $(p<0.05)$. It proves that there are no interactions between the covariance and the treatment.

Table 5 Univariate analysis of the ANCOVA

\begin{tabular}{|c|c|c|c|c|c|c|c|c|}
\hline Test & Gr. & $\mathrm{N}$ & Mean (In.) & Mean (Fin.) & Adj. Mean & $\mathrm{F}$ & $\mathrm{P}$ & $\begin{array}{c}\text { P. Eta } \\
\text { Squ. }\end{array}$ \\
\hline \multirow{2}{*}{ SJ } & $E$ & 15 & 21.91 & 27.84 & 25.58 & \multirow{2}{*}{93.384} & \multirow{2}{*}{0.000} & \multirow{2}{*}{0.776} \\
\hline & $\mathrm{K}$ & 15 & 23.30 & 24.68 & 23.94 & & & \\
\hline \multirow{2}{*}{ CMJ } & $E$ & 15 & 24.76 & 29.74 & 29.80 & \multirow{2}{*}{20.272} & \multirow{2}{*}{0.000} & \multirow[b]{2}{*}{0.429} \\
\hline & K & 15 & 24.89 & 27.02 & 26.96 & & & \\
\hline \multirow{2}{*}{ DJ } & $E$ & 15 & 28.04 & 32.87 & 33.13 & \multirow{2}{*}{30.313} & \multirow{2}{*}{0.000} & \multirow{2}{*}{0.529} \\
\hline & $\mathrm{K}$ & 15 & 28.80 & 28.34 & 28.08 & & & \\
\hline \multirow{2}{*}{ OLCMJ } & $E$ & 15 & 12.03 & 15.70 & 15.24 & \multirow{2}{*}{4.637} & \multirow{2}{*}{0.040} & \multirow{2}{*}{0.147} \\
\hline & $\mathrm{K}$ & 15 & 11.03 & 12.50 & 12.96 & & & \\
\hline
\end{tabular}

Explanation: $\mathrm{Gr}$ - group; $\mathrm{E}$ - experimental group; $\mathrm{K}$ - control group; $\mathrm{N}$ - the number of examinees; Mean (In.) - the mean value of the initial measuring; Mean (Fin.) - the mean value of the final measuring; Adj. Mean - the adjusted mean values of the final measuring which had the effects of covariance statistically removed; $\mathrm{F}$ - the F-test value (the test which checked the significance of the difference between arithmetic values; $\mathrm{p}$ - the coefficient of the significance between the arithmetic values;

P. Eta Squ (Partial Eta Squared) - the magnitude of influence

After the statistical removal of the effects that the results obtained from the testing that evaluated the explosive power before the treatment had, it was determined that there was a statistically significant difference on the univariate level between the participants of the $\mathrm{E}$ and $\mathrm{K}$ groups in $\mathrm{SJ}$ test $(\mathrm{F}=93.384 ; \mathrm{p}=0,000)$. On the basis of the adjusted mean values (Adj. Mean, from which the influence of the covariance was statistically removed), it can be seen that the $\mathrm{E}$ group participants had better results (Adj.Mean $=25.58$ ) when compared to the ones that the $\mathrm{K}$ 
group participants achieved (Adj.Mean $=23.94)$. Partial eta squared $($ Partial Eta Squared= 0.776 ) shows that the difference is great. In Koen: 0.01 - little influence, 0.06 - medium influence, 0.14 and more - large influence (Pallant, 2007).

\section{DISCUSSION}

The results obtained showed that the experimental group had made a statistically significant improvement in the squat jump (SJ) and drop jump (DJ) compared to the control group. Voelzke, Stutzig, Thorhauer, \& Granacher (2016) had similar results in their study designed to examine the effects that a combined training process had on the development of explosive power. The sample of their participants consisted of the elite German volleyball players. The participants $(\mathrm{n}=16)$ were divided into two experimental groups; E1 $(\mathrm{n}=8)$, in which a programme designed from resistance training and plyometrics $(\mathrm{RT}+\mathrm{P})$ was applied and E2 (n $=8$ ), in which electrical muscle simulation was combined with pylometrics (EMS + P). After the experimental treatment, which lasted for five weeks, the researchers concluded that RT + P programme contributed to the statistically significant improvement in the squat jump test $(+2.3 \%)$ and the height of reach from a three-step jump $(+0.4 \%)$. Further comparison of the differences between the groups showed a statistically significant difference in the squat jump test in favour of the RT $+\mathrm{P}$ group ( $\mathrm{p}=0.023)$, as well as significant improvement in the DJ test results in favour of the group in which EMS + P programme had been conducted.

The experimental group in our research showed a statistically significant improvement when compared to the control group in the Countermovement Jump test (CMJ) between the initial and final measurements. Moreno, Asencio, \& Badillo (2014) obtained similar results, since they determined a statistically significant improvement in the explosive power in the CMJ test in favour of the experimental group after a six-week-long experimental treatment. The

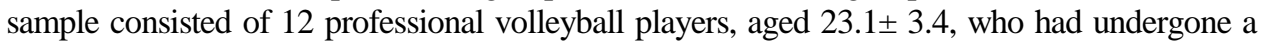
combined training process consisting of pylometrics and weight training.

The results obtained proved that there was no statistically significant difference between the initial and final measurements with both groups of participants (E and K) in OLCMJ test. Leporace et al. (2013) obtained similar results after they had conducted a six-week-long training programme, which combined pylometrics and balance training, among 15 female volleyball players aged $13 \pm 0.7$. The researchers proved that there was no statistically significant improvement in the explosive power in the one-leg countermovement jump (OLCMJ). Kostanić, Cigrovski, \& Prlenda (2011) got the same results after determining the effects of an eight-week training process on the explosive power development. The sample of participants in their research was comprised of 13 senior volleyball players. Although the explosive power was evaluated by five tests (SJ, CMJ, OLCMJR, OLCMJL, and CJ), statistically significant qualitative changes in favour of the experimental group were made in SJ and CMJ tests only. Such results find justification in the fact that in almost all the situations in a volleyball game jumps are performed by a two-leg take off. The exception to this is the first tempo behind the head, in which the middle block performs a diagonal running start with the take-off on the leg opposite to the arm that spikes. Taking into account the fact that the sample of participants in this research was made up of young female volleyball players aged 14 to 16 , who had just specialized in their players' positions, the unfavourable results in the OLCMJ test could be justified. Another thing is that when creating a programme within the experimental treatment not too much attention is paid to 
performing one-leg jumps due to the fact that contemporary training process focuses on doing those exercises that would resemble a real game (situational training).

Comparing the magnitude of influence of the experimental treatment based on the Partial Eta Squared parameter between the SJ, CMJ, and DJ tests, we can conclude that the Partial Eta Squared for CJ is 0.776, for CJ 0.492 and for DJ 0.529, which implies that there is a great difference in the mean values for both groups in all the three tests. From this comparison we observe that the biggest value, and with it the strongest effect of the experimental tratment, in the SJ test, then in the DJ test, whereas the least significant effect can be noted in the CMJ test.

The duration of the experimental programmes described in the works of the authors who explored this issue varied from four weeks (Elif, Ahmet, Mustafa, Elvan, \& Ozge, 2010) to as much as nine months (Sabin, Alexandru, 2015). A twelve-week experimental treatment was conducted in two studies (Memagić, Balić, Novaković, Bilić, \& Redžić, 2011; Mannan, Johnson, Avalaiah, \& Nathaniel, 2015), which had a similar outcome. The study conducted by Memagic et al. (2011) had a sample of female volleyball players aged 14 to 16, just as in this one. The results of that study showed that there were qualitative changes in the explosive power in fvaour of the experimental group. Similarly, the applied twelve-week experimental treatment in the study conducted by Mannan et al. (2015) resulted in the statistically significant improvement of the explosive power of jump in favour of the experimental group.

Technical and tactical training sessions that were conducted within the control group were comprised of jumping while performing the elements of volleyball, so there was certain improvement in the results of the tests applied. However, those improvements were not statistically significant, only numerically. This fact proves that the applied treatment, which lasted for 12 weeks, had positive effects and that it is absolutely applicable in the volleyball training process with the aim of developing explosive power while jumping.

\section{CONCLUSION}

The results of the conducted longitudinal research show that a specially programmed twelve-week training process led to a significant improvement in explosive power while jumping in three out of four tests applied within the experimental group. Volleyball coaches and experts need exercises that can, in the shortest period of time possible, improve explosive power as one of the necessary factors for achieving success in this sport, reducing the chances for injuries. The programme designed for the purpose of this research meets these criteria, which is proven by the obtained results.

\section{REFERENCES}

Elif, O., Ahmet, P.H., Mustafa, A., Elvan, O., \& Ozge, P.A. (2010). The effects of 4 month volleyball training on flexibility, jump, speed and agility in preadolescent girls. Ovidius University Annals, Series Physical Education and Sport, 2, 558-560.

Ignjatović, A., Radovanović, D. (2013). Physiological bases of training of the strength (second edition). University of Niš: Faculty of Sport and Physical Education.

Janković, V., Janković, G., \& Đurković, T. (2003). Specific physical preparation of top volleyball players. In D. Milanović (Ed.), Proceedings of the International Symposium. Conditioning of athletes. (pp. 229-237),

Zagreb: Faculty of Kinesiology. 
Kostanić, D., Cigrovski, V., \& Prlenda, N. (2012). Can explosive leg strength of volleyball players be improved during competitive season? Anthropological Aspects of Sports, Physical Education and Recreation, 6(2), 211-221.

Kovijanić, B. (2014). Physical preparation of volleyball players, University of Belgrade, Faculty of Sport and Physical Education.

Leporace, G., Praxedes, J., Pereira, G.R., Pinoto, M.S, Chagas, D., Metsavaht, L., Chame, F., Batista, L.A. (2013). Influence of a preventive training program on lower limb kinematics and vertical jump height of male volleyball athletes. Physical Therapy in Sport, 14(1), 35-43.

Mannan, S., Johnson, P., Avalaiah, N. \& Nathaniel, S. (2015). Study on volleyball specific plyometric training on speed power and agility of male volleyball players. International Journal of Law, Education, Social and Sports Studies, 2(3), 226-229.

Memagić, A., Balić, A., Novaković, R., Bilić, M., \& Redžić, H. (2011). Rartial quantitative changes of explosive strength and agility under the influence of a special program. Sports Logos, 21(4), 216-221.

Moreno, S.M., Asencio, C.G., Badillo, J.G. (2014). The effects of short-term resistance program on vertical jump ability in elite male volleyball players during the competition season. Nuevas Tendencias en Educación Física, Deporte y Recreación, 26(1), 153-156

Nejić, D, Herodek, K., Živković, M., \& Protić, N. (2010). The development of explosive strength in volleyball. In Stanković R. (Ed.), Proceedings of the XIV International Scientific Conference - "FIS Communications 2010 in Sports, Physical Education and Recreation " (pp. 276-285) Niš: Faculty of Sport and Physical Education, University of Nis.

Pallant, J. (2007). SPSS survival manual: A step-by-step guide to data analysis using SPSS version 15. Nova Iorque: McGraw Hill.

Sabin, S.I., \& Alexandru, S.D. (2015). Testing agility and balance in volleyball game. Research Gate

Stojanović, T., Kostić, R., \& Nešić G. (2005): Volleyball. Faculty of Sport and Physical Education, Banja Luka.

Voelzke, M., Stutzig, N., Thorhauer, H.A., \& Granacher, U. (2012). Promoting lower extremity strength in elite volleyball players: effects of two combined training methods. Journal of Science and Medicine in Sport, $15(5), 457-462$.

\section{EFEKTI PROGRAMIRANOG TRENINGA NA RAZVOJ EKSPLOZIVNE SNAGE ODBOJKAŠICA}

Cilj istraživanja bio je utvrđivanje efekata programiranog treninga na razvoj eksplozivne snage mladih odbojkašica. Uzorak ispitanika činilo je 30 odbojkašica uzrasta od 14 do 16 godina, članica OK "Desetka" i OK "Millennium" iz Niša. Celokupan uzorak ispitanica bio je podeljen u dve grupe. Eksperimentalnu grupu (n=15) činile su odbojkašice OK "Desetka" koje su u okviru osnovnih tehničkotaktickih treninga, 2 nedeljno bile podvrgnute specijalno dizajniranom programu za razvoj eksplozivne snage. Kontrolnu grupu $(n=15)$ činile su odbojkašice OK „Millennium“koje su trenirale po godišnjem planu i programu svog kluba. Eksperimentalni tretman sproveden je u pripremnom periodu, u uvodnom delu treninga. Uzorak mernih instrumenata za procenu eksplozivne snage činila je baterija od četiri testa: skok iz čučnja (SJ), skok iz čučnja sa pripremom (CMJ), dubinski skok (DJ) i skok iz čučnja sa pripremom odrazom jedne noge (OLCMJ). Obrada podataka izvršena je uz pomoć programa SPSS20. Za utvrđivanje normalnosti distribucije varijabli korišćen je Kolmogorov-Smirnov test. Za utvrđivanje efekta programiranog treninga na razvoj eksplozivne snage odbojkašica, korišćena je analiza kovarijanse ANKOVA. Dobijeni rezultati ukazali su na statistički značajno poboljšanje u praćenim parametrima u korist eksperimentalne grupe na tri od četiri primenjena testa. Razlika između grupa nije bilo samo na testu OLCMJ. Na osnovu dobijenih rezultata možemo zaključiti da je primenjeni eksperimentalni tretman imao pozitivne efekte na razvoj eksplozivne snage mladih odbojkašica.

Ključne reči: odbojka, motoričke sposobnosti, eksplozivna snaga, efekti 